\title{
Racist Aspects of Modern Turkish Nationalism
}

\section{Ilia Xypolia}

\section{University of Aberdeen, UK}

\section{Abstract:}

This paper aims to challenge simplifications on race and racism in contemporary Turkish society. In doing so, it draws a macro-historical context wherein the racist component of the Turkish national identity had been shaped. The paper traces the emergence of the core racist elements in the beginning at the $20^{\text {th }}$ century within the ideology propagated by the organisation of the Turkish Hearths (Türk Ocaklar1). The Turkish History Thesis with its emphasis on 'race' attempted to promote not only an affiliation but also a common ancestry between Turkish and Western Civilisation. These arguments were backed by commissioning research carried out in the fields of Anthropology, Archaeology and Linguistics. The main argument of this paper is that the racist components of the national identity in Turkey have been the product of a Eurocentric understanding of world history by consecutive nationalist leaders.

Keywords: Racism, Eurocentrism, Nationalism, Whiteness, Turkey.

An important but significantly under-researched theme of Turkish national identity over the course of the last 100 years has been its racist elements. Indeed, historians and other social scientists have paid little attention to the racist and racial elements in the shaping of the Turkish national identity. The scholars that have examined related issues seem to have solely focused on Turkish state's treatment of its own ethnic minorities, notably the Kurds, the Armenians, the Jewish population of 
Turkey and the Greeks. Many official accounts and historical narratives of Turkish nationalism and its practices omit to fully grasp the development of the ideas based on Turkishness as a 'pure race'. The historical construction of race could be examined as a wider system of power and oppression. The denotations of any given race are not static as they reside in the juncture of politics in that historical context. To provide a framework for a better understanding of the permanence of these phenomena we should look at the global racial hierarchy.

A racial hierarchy is a system of stratification that concentrates on the conviction that some racial groups are either superior or inferior to other racial groups. The groups identified to have the most power and influence are at the top of the racial hierarchy, while the groups recognized to be inferior are at the bottom. A global racial hierarchy in which white Europeans were considered inherently superior to all other 'races' in practically every respect was central for colonial/ imperialist expansion in all parts of the world, as well as for the formation and system of slavery. Without the declared conviction that white people are superior intellectually, spiritually, artistically - than non-white people, it would not have been conceivable to subordinate and dehumanize subjugated peoples. In the world today, there still appears to be a reasonably common opinion, both among academics and the wider public, that white Europeans / Americans are at the top of this racial hierarchy. Martin Jacques explains the reasons for this as follows:

At the top of this hierarchy are whites. The reasons are deep-rooted and profound. White societies have been the global top dogs for half a millennium, ever since Chinese civilisation went into decline. With global hegemony, first with Europe and then the US, whites have long commanded respect, as well as arousing fear and resentment, among other races. Being white confers a privilege, a special kind of deference, throughout the world, be it Kingston, Hong Kong, Delhi, Lagos - or even, despite the way it is portrayed in Britain, Harare. Whites are the only race that never suffers any kind of systemic racism anywhere in the world. And the impact of white 
racism has been far more profound and baneful than any other: it remains the only racism with global reach. ${ }^{1}$

Racism is a modern phenomenon and a product of the capitalist system. ${ }^{2}$ According to Wallerstein race, and therefore racism, is the 'expression, the promoter and the consequence of geographical concentrations associated with the axial division of labour'. ${ }^{3}$ As such racism should be conceived as a global process embedded in a hierarchical development of the world-system. Racial categories are a social construction and have always form a global hierarchy. Yet, as race is a dynamic and fluid construct, the names and the boundaries of the categories are in regular flux adjusting to new circumstances and changing interactions with various manifestations of power. In particular, 'white race' and 'whiteness' constantly modifies their meaning by including different groups.

In this paper, the over emphasis of, and even obsession with, 'whiteness' in early definitions of Turkish identity should be scrutinised as a by-product of Eurocentrism. Eurocentrism is the discourse that places emphasis on European concerns, culture and values at the expense of those of other cultures. Eurocentrism as a practice is a modern phenomenon that dates back to the sixteenth century, the period of the Renaissance, and emerges most strongly in the nineteenth century and gains further momentum in academia in the twentieth century. Samir Amin considers Eurocentrism as an ideological distortion and thus describes it as a world view fabricated by the domination of Western capitalism that claims European culture reflects the unique and most progressive manifestation of the metaphysical order of history. ${ }^{4}$ One of the most fundamental myths of Eurocentrism is the socalled European miracle, also known as the Great Divergence, the process where European countries gradually grew to become the most powerful global economies. Traditionally the great narrative of the rise of Western civilisation attributed European success to cultural values, social institutions and political practices. 
Eurocentric narrative stresses the culture and institutions of European 'exceptionalism' that led to the industrial growth of Northwest Europe. On the contrary, revisionist historians who challenged the Eurocentric narrative argue that the European miracle should be considered as a process that emerged in the nineteenth century due to two fortuitous circumstances: convenient coal supplies and access to the abundance of the New World. 5 This view focuses on a more global context in order to place the so-called European miracle within the evolving patterns of global economic and cultural interaction. 6

While Eurocentrism should not be equated with racism, a Eurocentric approach to world history can provide a solid basis for the development of racist ideas. The so-called modernisation project delivered by Kemalist reforms in the first two decades of the Republic's lifespan was formed with a purely Eurocentric assumption of modernity and progress.

In order to understand the shape that the Turkish national identity took in the emergence of the Republic of Turkey in 1923 we should trace its historical trajectory in a global context. Historians point out the 1683 military defeat in Vienna of the Ottoman army as a turning point for the history of the empire. In the relevant literature the siege of Vienna marks the beginning of the relative decline of the Ottoman Empire. The Eurocentric literature and public discourse in the nineteenth century referred to the Ottoman state as the 'sick man of Europe'. The root of the Ottoman decline attributed to intellectual and cultural backwardness. ${ }^{7}$ By attributing to the so-called 'European miracle', and its cultural and racial characteristics, the same literature perceived the Ottoman and Islamic world as culturally 'inferior'. The binary opposition between the 'dynamic' and the 'static' was a recurrent theme in the Eurocentric narrative of the world. 
This paper argues that Kemalism developed its reforms by blindly adopting Eurocentric racist assumptions. Kemalism can be perceived as the extension of certain ideas on global development and race initially emerged in the nineteenth century. The theory and ideology of Turkism has been developed on these Eurocentric explanations for the decline of the Ottoman Empire and the assumption of the superiority of the Western civilization. The wide-spread belief was that only by dogmatically embracing the so-called western values and political and economic systems the Turkish state would regain its power.

\section{Mislabelling Kemalism in Civic and/or Ethnic nationalism terms}

Hans Kohn' classic typology of 'liberal civic Western' / 'illiberal ethnic Eastern nationalism' symbolises the epitome of Eurocentric biases in the academic field of studies of nationalism. ${ }^{8}$ This typology is so well established that many scholars still apply these sharp distinctions in studies of empirical cases. The case of Kemalism in Turkey is not an exception to this academic tradition. Few critical scholars like the Marxist Perry Anderson perceive that Kemalism represented a purely ethnic type of nationalism that was intentionally masqueraded as civic. ${ }^{9}$ Studies are very reluctant to characterise Kemalism as purely ethnic and go as far as to describe two faces of Kemalist Turkish nationalism, one inclusive and one exclusive. ${ }^{10}$ However, for the vast majority of scholarly work Kemalist nationalism is widely characterised as a civic nationalism that eventually transformed and incorporated some ethnic elements. They usually support their claim of the 'civic' character of Kemalism on two grounds. Firstly, they cite article 88 of the 1924 Constitution that dictated that the inhabitants of Turkey are considered as Turks by virtue of citizenship irrespective of religious and racial differences' 11 as evidence of the inclusiveness of the Turkish national identity. Secondly, scholars illustrate their claim for the civic 
type of nationalism by quoting the -what came to become- the national slogan of the Republic 'Ne mutlu Türküm diyene' (How happy is the one who says, 'I am Turk') coined by Mustafa Kemal. This phrase encapsulates Ernest Renan's civic view of the nation as a 'daily plebiscite' highlighting the voluntary choice for an association with a nation. Thus the Kemalist form of Turkish nationalism is widely conceived by the vast majority of scholarly work as civic in origin, rather than ethnic. In this paper we shall move beyond this distinction that rather obscures than reveal the nature and the characteristics of a certain form of nationalism.

The adherents of Kemalism were French-educated scholars that professedly pursue a civic conceptualization of the nation. Two of the most influential ideologues of the early twentieth century are undoubtedly Yusuf Akcura(oglu) and Ziya Gokalp. Yusuf Akcura (1876-1935) in his 1904 essay, Üç Tarz-ı Siyaset (three versions / types of politics) presented the ideological debate that was going on for a while among intellectuals of the declining Ottoman Empire. ${ }^{12}$ Ottomanism, originated in the 1860s, was the idea that the mosaic of communities will fuse into one Ottoman citizenry if all the subjects of the Empire would be equal. The second one was Islamism that was based on the idea that a regeneration of the Ottoman state was lying in return to Islamic values and law. Finally, the third current was Turkism. The question of race was central in the work of Akcura.

Ziya Gokalp (1876-1924) was probably the most significant ideologue in the shaping of the Turkish nationalist project. The work of the prolific Turkish intellectual was highly influenced by the French sociologist Emile Durkheim in his conceptualisation of culture and civilisation and the ideas of progress. Same as the most eminent western sociologists, Durkheim's work is underpinned with the Eurocentric binary distinction of modern and traditional societies. ${ }^{13}$ This distinction is the central basis upon which Gokalp developed his understanding of culture and 
civilisation. While in western world progress is a natural route, in the non-western world progress will be achieved only by adopting western ideas and values. Ziya Gokalp urged the compatibility of Turkish nationalism, Islamic culture and western civilization. In doing so, he considered western civilization as more broad than Christianity. He considered that religion constitutes the culture of a society. So Islam is simply the culture of the society and not the civilisation. The understanding of civilization and culture as separate entities paved the way to argue for the compatibility of civilization and culture and in particular Western civilization and Islamic culture.

Gokalp's ideas have long been perceived as downgrading racism by promoting cultural nationalism. ${ }^{14}$ Literature on Gokalp has emphatically rejected any racist connotations that attributed to his work and theory. His 'sociological' definition of the nation held that 'nation is not a racial, ethnic, geographical, political, or voluntary group or association. Nation is a group composed of men and women who have gone through the same education, who have received the same acquisitions in language, religion, morality, and aesthetics. The Turkish folk express the same idea by simply saying: "The one whose language is my language, and whose faith is my faith, is of me." Men (sic) want to live together, not with those who carry the same blood in their veins, but with those who share the same language and the same faith. Our human personality is not our physical body but our mind and soul."15 This quote has been cited in order to support the view that Gokalp was anti-racist and advocator of a voluntarily, civic approach to nationalism. Though on a number of occasions, Gokalp attempted to synthesize the currents of Islam and Turkism in the ideological debates, this position assumed the existence of the race that was only temporarily and instrumentally omitted. 
Yet, Gokalp's ideology is being developed within a context shaped by pure Eurocentric and racist understanding of world history. This racist understanding is often explicit in his writings. For instance, Gokalp writing on Western imperialism put forward a pure racist argument for explaining imperial expansion. Gokalp held that 'as the black and red races were inferior in terms of intelligence and skill, the white master could not make enough fortune. In order to be a good worker in today's standard of agriculture and industry, it is necessary to have a high level of civilization'. ${ }^{16}$ Gokalp's ideological reading of history places the emphasis on culture and civilization at the expense of economic arguments.

The global racial hierarchy was not eroded even by the occupation of the Ottoman capital by British, French and Italian troops in accordance with the Armistice of Mudros. It is worth emphasising the British view of the Turkish perception of race during the occupation of Istanbul between 1918 and 1923. The British occupiers reported that "though the Allied Powers were Christians, they were respected as race apart and not be thought of as 'Giaours'." 17 This perceived respect of the 'white race' of the occupiers is striking given the odious situation of the foreign occupation.

Following the departure of the last Greek soldiers from Anatolian soil on 15 September 1922, the ceasefire of 11 October and the evacuation of eastern Thrace by the Greek army, the Lausanne peace conference opened. While the conference maintained suspense over the conclusion of peace, the year 1923 marked the establishment of the basic institutions, as well as the policies, of the new Turkey. During this time, Mustafa Kemal developed his critique of the economic backwardness of his country and its Islamic culture, and introduced his main goal as how to achieve western standards of political and economic management, in other words 'to make Turkey European'. This consists of a totally Eurocentric approach 
that neglects the fact that the concept of 'Europe' has change dramatically over time. Mustafa Kemal's understanding of Turkishness can be connected to an earlier debate, which centred around the Young Turk revolution of 1908.

The idea of Turkishness, or Turkism as it was first discussed, was widely inserted in the Ottoman Empire from the Russian émigrés after the Young Turk revolution in 1908. ${ }^{18}$ The Pan-Turkish program envisaged a unification of the Turkic people on the basis of common historical roots. One of the most significant institutions founded at that period was the Turkish Hearths (Turk Ocaklari). The Turkish Hearths, an organization close to the Committee of Union and Progress (CUP), was an effective organ in the applied 'Turkification' process. Still, gradually these Pan-Turkish aspirations were losing momentum and the Turkish current of ideology started focusing on Anatolia. ${ }^{19}$ However, Kemalism should be understood as a sect from the Young Turks movement. The ideology of the Young Turks movement is considered as the continuity of trends propagating Eurocentric modernisation ideas that were developed in the Ottoman Empire at least since the middle of the nineteenth century.

The Turkification project proceed by Kemalism sought to create an ethnically homogeneous Turkey. The 1923 Lausanne Peace Treaty the document that marked the birth of the Turkish Republic arranged the Republic's ethnic composition of the population in two ways. Firstly, it has provisions that formally recognized Christians (Armenian and Greek) and Jews as minorities in Turkey. However, Turkish delegation during the negotiation process insisted on refusing to attribute any distinct status for non-Turkish Muslims. This omission was the prelude of the Turkification project in the early days of the Republic that was aiming to assimilate the Muslim communities of Turkey. ${ }^{20}$ The second significant provision for the composition of the population was the population exchange between Turkey and 
Greece. It should be considered as an integral part of the Turkification process preached by Kemalist ideology. This forced and legally institutionalised bilateral population exchange is widely discussed as the epitome of an ethnic population policy. Therefore, it is not surprising that by that time in German press the growing debate on Ataturk's policies and reforms attempted to understand them in connection to the Nazis' principle of ethnic homogeneity. The perception of Turkey's "ethnically homogeneous" success story appears in the Nazi public discourse during the interwar period. Being against multi-ethnic entities Nazi commentators praised the so-called ethnic cleansing of Anatolia calling for adaptation to 'Turkish methods' for a solution to the minority questions. ${ }^{21}$ Yet, an overwhelming majority of scholarly work on Kemalist policies of assimilation have long considered them as anti-racist and diametrically opposite to segregation policies. ${ }^{22}$

The Turkification project as a part of Mustafa Kemal's modernisation process has been essentially conceptualised upon a racist and Eurocentric basis. Ataturk held the view that the new Turkey should cut all its "Eastern/ Muslim" origins adrift and define itself as part of the "White/ Western" civilization. He tried to prove this in many different ways for the rest of his life. The Turkish delegation at Lausanne sought to convince the British, French and Italian delegates that the Ankara government had nothing in common with the "old Eastern/ Muslim Turk" represented by the Ottoman Empire. Hence, the new Turkey, from the start, identified itself directly and immediately with the history, culture and perceptions of the western world, claiming a total break with the Ottoman and Islamic past. By 1925 an independent Turkish Republic was firmly established with its new westerntype institutions propagating a militantly secular modernising ideology. A completely new social order was created under the rule of a small secular military elite. The events of these early years mark an important watershed in the development of 
Turkish state ideology, which is still dominating most aspects of the Turkish state and society. ${ }^{23}$

Since the early 1930s the administrative apparatus had been using 'race' as an evaluative criterion for Turkish citizens. ${ }^{24}$ There were numerous occasions where the 'ethnic Turks' were treated as 'first-class' citizens while cases regarding citizens from the Republic's various minorities were dealt with prejudice and discrimination. It is worth noting that in 1935 the terms 'Turkish blood' and 'Turkish ethnicity' were being used interchangeably in official documents. ${ }^{25}$

The racist component of Kemalism is elucidated as practice and discourse in various policies and speeches delivered by ruling CHP cadres. ${ }^{26}$ At a valuation of the Kemalist reforms, a report prepared for the 1938 CHP conference lays out the pertinence of the modernisation project to the Turkish race. It stated that both Ataturk and the nation being "in constant contact and aware both of the march of events that the progress of civilization" they determined "what it was necessary to adopt and what to abandon in order for Turkey to become a modern state and the Turkish nation to take its place as the first in the history of the world" by "leveraging the capabilities and character of the Turkish race". ${ }^{27}$

\section{Turkish History Thesis: Inventing the long way back}

The 1930s Kemalist racist practice found a pseudo-scientific basis in the Turkish History Thesis (Türk Tarih Tezi). The 'Turkish History Thesis' attempted to scientifically support and legitimately popularise the racist ideas propagated by the Turkish Ojaks since the early 1910s. The despicable assertions of the Turkish History Thesis were a simple elaboration of Turkish Ojaks ideology. Like the Turkish 
Ojaks, the Turkish History Thesis placed Turkish race at the root of human civilisation and language.

The institution of the Turkish Ojaks has been the most effective channel of spreading Kemalist ideology to the population. It was founded in 1912 with the fourfold mission: "to reinforce the ethnic conscience among the Turks; to elevate their social and intellectual level; to purify their language; to increasing their economic prosperity". Rechid Safvet ${ }^{28}$ in his lecture on 7 June 1929 to the Turanian Society of Budapest $^{29}$ noted that with Kemal Ataturk Turks had passed to the third and last period in the three required stages of national formation. According to Safvet, "The Turks had always and profoundly the consciousness and the pride of their origins, their ascendances, so much that there was almost no leader among them that has stood with honour to trace back their ancestors to Altai, the birthplace of the white race itself'. ${ }^{30}$

After establishing the Turkish 'race' as a 'white' race, the Ojaks claimed that in ' $11^{\text {th }}$ century BC the word 'turk' was synonymous with 'noble' and 'superior' at central Asia". ${ }^{31}$ They stated that even the great Genghis Khan had proudly referred to his Turkish ancestry. The Ojaks traced the consciousness of nationality itself, in the sense that the French Revolution gave, and in which it was understood later in the rest of Europe, this conscience was awakened for the first time in Turkey at the beginning of $19^{\text {th }}$ century. The ideology of Turkish Hearths had been heavily influenced by the work of Ziya Gokalp. It was him who made the ancient claim for the land and the affinity toward Western civilisation. In Gokalp's understanding Western civilisation portrayed as a continuation of the ancient Mediterranean civilisation. According to Gokalp the 'ancient Turks were among the earliest founders of that Mediterranean civilization' and it was only that 'after attacks that they were forced to move to Far East only temporarily.'32 Likewise, the Turkish Hearths 
propagated the worldview that the Turkish nation laid the foundation of the Pelasgian, Etruscan, Chaldean, Egyptian and Chinese civilizations. ${ }^{33}$ Furthermore, it was also proclaimed that the Turkish language was one of the first languages spoken widely in the world, possessed all the elements of a language that is truly flexible and modern. ${ }^{34} \mathrm{All}$ these outrageous claims on race were based on Gokalp's work and systematically promulgated to the Turkish population through the numerous activities and publications of the Turkish Hearths. In 1930 Turkish Ojaks had 257 departments throughout the Republic with 32,000 members. The Turkish Hearths through their publications and their social and cultural activities played a crucial role for the implementation of the Kemalist cultural policies.

Ziya Gokalp classified the Turkish 'race' as the 'Altai'. He was convinced that future comparative studies on civilisation would "show the nature of the relation of the Turks to the groups called 'Altai' or 'Mongolian race'”. Gokalp asserted that 'to classify Turks who are fairer and more handsome than Aryans with the 'yellow race' has no scientific foundation, as the supposition of a linguistic unity among the ethnic groups, usually called the 'Altai race', is far from being proven. It is very probable that all of these groups all belonging to the Far Eastern civilisation. If this is so, our only affinity with Finno-Ugrians, Tunguz, and the Mongols consists of a common sharing of the same civilization of our domination over them for a long period. It is quite possible that through such an association certain similarities in language have taken place.'35 A decade later the research conducted under the auspices of the Turkish Historical Society provided pseudo-scientific coverage for these claims.

In the early 1930s Kemal Ataturk sought to legitimise these theories through the production of scholarly work. Under the patronage of Ataturk, the Turkish Historical Society (initially as Türk Tarihi Tetkik Cemiyeti and then as Türk Tarih Kurumu) founded as a body of the Turkish Ojaks in 1930. One of the founders of the 
Ojaks, Yusuf Akcura served as the President of the Society until his death in 1935. Through a series conferences and publications, the Turkish History Thesis that gave a sharp prominence to the role of race in defining the nation was established. The issues of the official journal of the society Belleten, conveying the official history thesis, yield insights on official perceptions of race.

In 1932, the first Turkish Historical Congress was convened in Ankara with the task of proving the theory that the Turks were indeed a white Aryan race originating in Central Asia where 'Western civilization' was assumed to have originated. ${ }^{36}$ The second Turkish Historical Congress met in Istanbul in 1937 before a major international audience, where further desperate steps were taken to prove that the Turks were indeed a central part of the white European race. Eugene Pittard, ${ }^{37}$ the Swiss anthropologist whose work was perceived and practiced as a racist account of humanity, not only participated but was announced as the honorary president. ${ }^{38}$ In a state-sponsored systematic effort missionary scientists employed to prove the identicalness of the Turkish race and the white' race by verifying that ancient Turks were the ancestors of modern European. In doing so, a selective reconstruction of historical events took place in order to suppress the Ottoman past and pursue Kemalism's political goal. In this way, Ottoman and Islamic principles became professed not only as an obstacle to progress but as its militant adversary.

The central theme of the Turkish History Thesis was the rejection of the Ottoman-Islamic past by glorifying the -invented- pre-Islamic past of the Turks. The sacred bond between language and nation is a recurring theme in the works nationalist scholars of the late 18th and 19th centuries. Eric Hobsbawm highlighting the 'invented traditions' as sine qua non practice in the nation-building process, states that they attempt to establish continuity with a suitable historic past. ${ }^{39}$ The 
suitably tailored discourse normally concerns a wide range of constructions and distortions found in established disciplinary knowledge. Thus Hobsbawm held that the study of 'invention of tradition' crosses the boundaries of history and should be interdisciplinary. The case of the racist 'invented tradition' proliferated by Turkish History Thesis is not an exception to this rule.

Following the articulation of the Turkish History Thesis, scholarly work in three disciplines - Anthropology, Archaeology and Linguistics - was instrumentally produced in order to verify the Turkish History Thesis. ${ }^{40}$ Numerous archaeological projects were commissioned with the purpose to research Hittite and 'prove' their Turkishness. Archaeological excavations and research were expected to corroborate all the major themes of the Turkish History Thesis, that is, the Turkishness of Anatolia, a secular history purified by Islamic tendencies, and equality between Turkish and European civilizations. ${ }^{41}$ The founding of museums was also an inherent part of the large-scale project of 'inventing the historical tradition'. ${ }^{42}$ The Museum of Anatolian Civilizations and the Ethnography Museum of Ankara were established in the early decades of the Republic to display the new archaeological discoveries to the wider public. ${ }^{43}$

Anthropological studies were first initiated with the establishment of the "Anthropology Research Center of Turkey" as part of the Medical School of Istanbul University in 1925. After the university reform it was placed under the roof of the Faculty of Sciences, as a separate Department of Anthropology. In 1935 it was renamed 'Turkish Institute for Anthropology and Ethnology' and was transferred to the School of Languages, History and Geography (Dil Tarih Coğrafya Fakültesi) in Ankara University. These changes signify the specialization of the discipline. The Center published the Journal of Turkish Review of Anthropology (Turk Antropoloji Mecmuas1) from 1925 untill 1939. The journal had close relations with the Ministry 
of Education with the Ministers being the honorary presidents of the journal. The official state approval and support of the Journal makes it a kind of think tank of the Republic. ${ }^{44}$ The published contributions elaborated a theoretical ground upon which the racist component of Turkish nationalism flourished. ${ }^{45}$

The goal of the anthropological research was twofold. On the one hand, it attempted to establish a 'racial continuity' in Anatolia since the Hittites and on the other, to prove the whiteness of the Turkish 'race'. The work of Afet Inan, the adopted daughter of Kemal Ataturk, acquired an authoritative status. Working at Geneva University under the supervision of Eugene Pittard, measured a wide range of skeletons in order to support her claims. Inan was also one of the main contributors of the Turk Tarihinin Ana Hatlari (Main Features of Turkish History) volume where the Turkish History thesis was first elaborated. This 605-page book served as a source for the production of the history textbooks and curricula in public education. The aim of the book, as laid out in its introduction, was "to reveal the mysteries of the Turkish genius and moral character, to demonstrate to the Turk himself his own uniqueness and power and to explain that our national development is embedded in deep racial roots." 46 Overall, anthropological research undertaken during the formative decades of the Republic put forward racist arguments in order to support the Turkish History Thesis.

Finally, a vital part of the Eurocentric Kemalist project was linguistic engineering. This multiple-step process took the form of language reform marked a violent rupture from the past. On 1 November 1928 the new alphabet, a modified version of the Latin alphabet, replaced the Arabic scripture. The adoption of the new Turkish alphabet aimed at facilitating communication with the West. ${ }^{47}$ In 1932 the Turkish Language Society was established and the terminology of race was employed. A special commission was set up in order to "renovate the Turkish language by 
discarding foreign words and locutions which have been adopted at different epochs and substituting in their place genuine and original Turkish equivalents, so that Turkish may regain its pristine "personality." 48 The purification of the Turkish lexicon and grammar from Persian and Arabic words was a part of the -negation of Ottoman past- process. ${ }^{49}$ These radical changes came to be called the Language Revolution (Dil Devrimi).

The commission carried out linguistic research for supporting two fundamental Kemalist claims. First, through comparative studies of languages sought to prove the unity of Turkish and Indo-European languages. The second aim was even more grandiosely outrageous than the first. Through establishing a tie between Sumerian and Turkish language, it endeavoured to assert that Turkish was the first language in human history. This assertion was eventually dropped in late 1930s. ${ }^{50}$ Ataturk has imposed on the commission a 'stupendous task, the magnitude of which would surely appal any recognised philologist, though it does not seem to daunt the ardent and self-complacent Turk, whose findings are not likely to carry much weight beyond the boundaries of his native land.' 51

In 1935 the 'Sun language theory' (Güneş Dil Teorisi) was launched. It sought to prove that Turkish language was the first in human history and the root of all Semitic and Indo-European languages. It was based upon a heliocentric view of the origin of civilization and human languages; the theory claimed that the Turkish language was the language which all civilized languages derived from. The association between the sun and language was founded in archaeological discoveries of the solar disks. The symbol of the sun disk thus indicated the Hittite prehistoric past of Turkey. ${ }^{52}$ This extravagant claim for the language should also be understood through the Eurocentric essence and nature of Kemalism. Sumerian and Hittite were considered as ancient Turkish languages in order to establish a racial claim to 
Western civilisation. In 1933, Ataturk himself was convinced 'European languages and civilisation had their origins among the Altai Turks many thousands of years B.C. and, in particular, that the Hittites were of Turkish stock'. ${ }^{53}$

The education was developed around these ideas. The interface between culture and education is demonstrated also in 1935 when the Ministry of Education (Maarif Vekaleti) was renamed the Ministry of Culture (Kultur Bakanligi). ${ }^{54}$ Since the early 1930s the official history textbooks have been rewritten according to the Kemalist ideology in education promulgating the 'Turkish History Thesis'. ${ }^{55}$ The use of this Thesis and its major themes had provided the framework where school textbook were structured and developed throughout the history of the Republic.

Dr. Resit Galip56, a Minister of Education who showed special interest in the linguistic and historical claims of Kemalism, summarised ten main points and themes underlying the official history in the 1930s. "Firstly, the cradle of mankind is Central Asia. Life first began and evolved there. Secondly, the world's first civilization was established in Central Asia by the Turkish race, the original people and first inhabitants. Thirdly, anthropologically, the brachycephalic Alpine type was representing the Turkish race. Fourthly, the large-scale migrations resulting from the contact of Europe and Asia took place from east to west, not from west to east. Fifthly, the Turks spread to different territories in wholesale migrations, the principal causes of which were the droughts which occurred at various epochs in Central Asia with increasing severity; they established ancient civilizations in those places. These civilizations, with a common source and creator, developed according to the particular conditions of the new surroundings. Sixthly, the Turkish language is the mother tongue. The correct solution of philological problems is impossible without taking into consideration the paleontology, archaic structure and formations of the Turkish language. Seventhly, as in the case of ancient civilizations (wrongly referred 
to as Islamic civilization) the role of foundation and achievement in the civilization of more recent epochs belongs to the Turks. Eighthly, in view of the fact that its climate most nearly approached the climate of Central Asia, and that from the geographical point of view it formed a bridge leading to Syria, Palestine, Egypt, the Aegean and the continent of Europe, the plain of Anatolia became Turkicised towards the end of the Paleolithic age, and this process spread with maximum rapidity in the chalcolithic (sic) age; by the end of the Selcuk era the currents of invasion and immigration which had flowed for thousands of years had made Anatolia, from the racial point of view, a stage representing Turkism in its purest and most unalloyed form, to such an extent that the ancient history of Turkism could be traced as much in Anatolia as in Central Asia. The ninth main theme was the inability of the Turkish nation during the last few centuries to fulfil its duty of historical guide in the progress and development of the world. This is an obstructive feature connected with obstructive caused and factors, though the racial setting which sets off the valuable and worthy jewels, is sound. Once the factors of obstructive decadence were removed by a process of revolution, the Turkish nation will once more resume its definite and essential duty of lighting the path of the undying historical work of civilization and the progress of mankind. This may be expressed in the formula: 'The Turkish nation has done, can do and will do'. Finally, the tenth major theme underpinning the new Turkish history was that because the analysis of the foregoing principles showed that, whereas the Ottoman theory of history neglected and denied the nation, the theory of Mustafa Kemal took the nation alone as its one subject, studies it, delves into it, makes it known, and selects formulae relating to its future exclusively from its history and past life. On the basis of this theory, nobody could say: 'My origin goes back to Noah,' or 'I am descended from Ali or Veli,' and in this way establish an ancestry by arranging his pedigree; nobody can establish false claims to pride of race if he ignores the Turkish nation. The Turkish nation alone is the foundation and 
origin." 57 This lengthy quote encapsulates the impact of the 'Turkish History Thesis' and the 'Sun Language Theory' on education. The scientifically fabricated theories that sought to establish the Turkish race as the founder of the Anatolian civilisation shaped also the official discourse on the non-Turkish Muslims like the Kurds. The forced assimilation, or Turkification, hence aimed to assimilate Kurds, a race that according to the above mentioned theories were originally Turks who had forgotten their Turkishness, into the Turkish nation.

\section{Conclusion}

Racism advocated by Kemalist was by no means a novelty in the 1930s. Racism was a widespread practice and theory worldwide. The uniqueness of the Kemalist project is the extent and abysmal impact on Turkish society. In a recently leaked document, the US Ambassador in Turkey in often-quoted observation questions the status reconciliation of Turkey with its past. He notes that 'the study of history and practice of historiography in the Republic of Turkey is subject to rigid taboos, denial, fears, and mandatory gross distortions'.58 It is now more than 90 years since the establishment of the Republic, and in an ever more complex and impersonal society, the limitations and contradictions of Turkish national identity are coming to the fore more and more. As Turkey moves deeper into the twenty-first century, a sense of confusion about ethnicity, nationhood, religion, secularity and the country's role in the world is very pronounced. The legacy of the practices of the early Republic lies in a continued emphasis by Turkish scholars on the 'civic' character of Kemalism. The Eurocentric essence of the distinction of forms of nationalism in good 'Western -civic' and bad 'Eastern -ethnic' urges the debate to move beyond these labels that obscure more than they reveal. 
Whereas the relationship between nationalism and racism has attracted much attention recently, the case of Kemalism has not been critically evaluated. Any study of the issue would require developing an understanding of the Eurocentric conceptualisation of the nation. The discourse developed in the 1990s on the formation and division between 'White' and 'Black' Turks, the Kurdish issue, treatment of other minorities and contemporary phenomena of xenophobia and racial discrimination cannot be fully understood without grasping the racist elements of Kemalism.

\footnotetext{
1 M. Jacques, 'The Global Hierarchy of Race', The Guardian, 20 September 2003.

${ }^{2}$ Immanuel Wallerstein, 'The Myrdal Legacy: Racism and Underdevelopment as Dilemmas', Cooperation and Conflict, 1989, 24(1), pp. 1-18

${ }^{3}$ Wallerstein, Immanuel (1991) [1987] "The Construction of Peoplehood: Racism, Nationalism, Ethnicity," in Etienne Balibar and Immanuel Wallerstein, Race Nation Class. London: Verso, pp.71-85.

${ }^{4}$ Samir Amin, Eurocentrism. Modernity, Religion, and Democracy, Monthly Review Press, New York, NY, 2009.

${ }^{5}$ Kenneth Pomeranz, The Great Divergence: China, Europe, and the Making of the Modern World Economy, Princeton University Press, Princeton, NJ, 2001.

${ }^{6}$ Andre Gunde Frank, ReOrient: Global Economy in the Asian Age, University of California Press, Berkeley, CA, 1998.

7 Jones' book on the 'European miracle', is a good example of the -still prevailing- Eurocentric assumptions about the decline of the Ottoman Empire. Eric Jones, The European Miracle: Environments, Economies and Geopolitics in the History of Europe and Asia, Cambridge University Press, Cambridge, UK, 1981.

${ }^{8}$ Hans Kohn originally invented the dichotomy Hans Kohn, The Idea of Nationalism, 1944, Macmillan, New York, NY. More recently, Michael Ignatieff's work puts forward the same dichotomous argument on civic and ethnic types of nationalism. According to Ignatieff, civic nationalism is democratic and 'maintains that the nation should be composed of all those-regardless of race, color, creed, gender, language, or ethnicity-who subscribe to the nation's political creed. This nationalism is called civic because it envisages' the nation as a community of equal, rights-bearing citizens, united in patriotic attachment to a shared set of political practices and values'. On the other hand, ethnic nationalism implies that 'that an individual's deepest attachments are inherited, not chosen" and that "it is the national community that defines the individual, not the individuals who define the national community." Michael Ignatieff, Blood and Belonging: Journeys into the New Nationalism, 1993, Macmillan, New York, NY.

${ }^{9}$ Anderson, P., 2008. Kemalism. London Review of Books [Online] vol. 30 no. 17 pp. 3-12. Available from http://www.Irb.co.uk/v30/n17/perry-anderson/kemalism [Accessed 3 September 2015].

${ }^{10}$ See Taha Parla and Andrew Davison, Corporatist Ideology in Kemalist Turkey: Progress or Order?, 2004, Syracuse University Press, New York, NY.

${ }^{11}$ Derya Bayir, Minorities and Nationalism in Turkish Law, 2013, Ashgate, Surrey, UK.

${ }^{12}$ Francois Georgeon, Aux origins du nationalisme turc: Yusuf Akcura (1876-1935), ADPF, Paris, 1980.

13 Frank, op. cit.

${ }^{14}$ For instance see Jacob M. Landau, Pan-Turkism: From Irredentism to Cooperation, Hurst Publishers, London, 1995.

${ }^{15}$ Ziya Gokalp, Turkish Nationalism and Western Civilization. Selected Essays of Ziya Gokalp,

Translated and Edited by Niyazi Berkes, George Allen and Unwin Ltd, London, 1959, pp.136-137.

${ }^{16}$ Ziya Gokalp, Makaleler VII (Kucuk Mecmua'daki Yazilar) [Articles VII: Essays on Kucuk
} 
Mecmua] Kultur Bakanligi Yayinlari, Ankara, 1982, p.151. As cited in Turan, Omer, 2012. Facing Eurocentrism, Facing Modernity: Questions of Modernization and Global Hierarchies in Turkish Intellectual History.

Unpublished PhD thesis, Central European University, Hungary.

${ }^{17}$ The National Archives, London, UK [henceforward TNA] TNA: WO 157/1309 (1923) 'A history of the

Nationalist Movement, 1918-1922; volume 1'. War Office's Intelligence Summary on 'Turkey: a history of the Nationalistic Movement, 1918-1922'.

18 Jacob M. Landau, Pan-Turkism in Turkey: A Study of Irredentism, Hurst, London, 1981, pp. 28-71.

${ }^{19}$ Erik-Jan Zurcher, The Young Turk Legacy and Nation Building. From Ottoman Empire to Ataturk's Turkey, I.B. Tauris, London, 2010. Page 215.

${ }^{20}$ Erol Ülker, 'Assimilation of the Muslim communities in the first decade of the Turkish Republic (1923-1934)', European Journal of Turkish Studies, < http://ejts.revues.org/822> (3 September 2015).

${ }^{21}$ A recent monograph by Stefan Ihrig sheds light on the Nazi perceptions about Mustafa Kemal and his reforms in the early days of the Republic of Turkey. According to Ihrig, Nazis often perceived Kemalism as a role model for them. Ihrig highlights Nazi's admiration for the suppression of religion in Turkey's political and social life, not least because Islam was portrayed as 'Arabic invention'. (page 187). [Stefan Ihrig, Ataturk in the Nazi imagination, The Belknap Press of Harvard University Press, Cambridge, MA, 2014. ] p179.

${ }^{22}$ Ayturk elaborates on the defence of Kemalist policies. Ayturk, Ilker, The Racists Critics of Ataturk and Kemalism from the 1930s to the 1960s. Journal of Contemporary History, 46(2):308-335.

${ }^{23}$ B. Gokay, 'From Western Perceptions to Turkish Self-Perception', Journal of Mediterranean Studies, 5(2), 1995, pp.259-269.

${ }^{24}$ Soner Cagaptay , Islam, Secularism and Nationalism in Modern Turkey: Who is a Turk?, Routledge, London, 2006.pp.79-80.

${ }^{25}$ Cagaptay, Soner,2006. Islam, Secularism and Nationalism in Modern Turkey: Who is a Turk?. London: Routledge.pp.79-80.

${ }^{26}$ The Republican People's Party (Cumhuriyet Halk Partisi - CHP) was established in 1923 by the leaders of the Turkish War of Independence and became the sole political organisation of the single-party state till 1945 and a major one ever since. Mustapha Kemal's modernization program was based on six basic principles (republicanism, populism, nationalism, secularism, statism and reformism) that are reflected in the six arrows of the flag of CHP party.

${ }^{27}$ The Prime Minister's Republican Archives, Ankara, Turkey (Başbakanlık Cumhuriyet Arşivi), [henceforward BCA], BCA: 490/01/1291/287 (1938) Document on 'The birth of the Republic of Turkey' prepared for the 3rd conference of the CHP in Istanbul on 7-14 April 1938.

${ }^{28}$ Deputy of the Turkish National Assembly and a delegate at the Lausanne Conference, 1922-1923 (signed as Kara-Schemsi).

${ }^{29}$ TNA: FO 371/14579 (1930) 'Turkey. Code 44 Files 961 - 1511 (to paper 2185)'. Safvet, Rechid, (1930) Les Turk-Odjachis, Ankara.

${ }^{30}$ TNA: FO 371/14579 (1930) 'Turkey. Code 44 Files 961 - 1511 (to paper 2185)'. Safvet, Rechid, (1930) Les Turk-Odjachis, Ankara.

31 TNA: FO 371/14579 (1930) 'Turkey. Code 44 Files 961 - 1511 (to paper 2185)'. Safvet, Rechid, (1930) Les

Turk-Odjachis, Ankara.

32 Gokalp, Turkish Nationalism and Western Civilization, op. cit., p. 267.

33 TNA: FO 371/14579 (1930) 'Turkey. Code 44 Files 961 - 1511 (to paper 2185)'. Safvet, Rechid, (1930) Les Turk-Odjachis, Ankara.

34 TNA: FO 371/14579 (1930) 'Turkey. Code 44 Files 961 - 1511 (to paper 2185)'. Safvet, Rechid, (1930) Les Turk-Odjachis, Ankara.

35 Gokalp, Ziya (1923) 'Towards Western Civilisation', p.271. (in Berkes 1959)

${ }^{36}$ It is worth noting that there were few academics and intellectuals that have raised some concerns over the Kemalist 'Turkish History Thesis' at the first Congress. However, they were 'silenced' at the second Congress five years later. Ersanlı-Behar, B. 1992. Iktidar ve Tarih: Turkiye'de "Resmi Tarih" Tezinin Olusumu (19291937), Istanbul: Afa Yayınları.

${ }^{37}$ Pittard wrote his Race and History in 1926, where he sets out a definite relationship between race and social behaviour based on a study of human skulls and brains and classifying various racial groups according to their intellectual capabilities. Eugene Pittard advised Ataturk's adopted daughter Afet Inan to complete her research on the superiority of the Turkish 'race'. L'Anatolie, le Pays de la "Race" Turque: Recherches sur les Caractères Antroplogiques des Populatios de la Turquie (Geneva: Librairie de l' Université Genève, 1941). 
${ }^{38}$ Gokay, Bulent, 'Race and Racism in Modern Turkey', openDemocracy, 5 November 2014, https://www.opendemocracy.net/arab-awakening/bulent-gokay/race-and-racism-in-modern-turkey (accessed in August 2015).

39 'Invented tradition' is taken to mean a set of practices, normally governed by overtly or tacitly accepted rules and of a ritual or symbolic nature, which seek to inculcate certain values and norms of behaviour by repetition, which automatically implies continuity with the past'. Hobsbawm, Eric (2004) Introduction: Inventing Traditions. In E. Hobsbawm and T. Ranger (eds.) The Invention of Tradition. Cambridge University Press.

${ }^{40}$ Etienne Copeaux (2008) 'Citoyenneté turque, territoire anatolien,' Presentation at l'ENS, Paris, 19 February. Online accessible at: [http://www.susam-sokak.fr/pages/Citoyennete_turque_territoire_anatolien_20082893654.html]

${ }^{41}$ Çiğdem Atakuman, 'Cradle or crucible: Anatolia and archaeology in the early years of the Turkish Republic (1923-1938)', Journal of Social Archaeology, 2008, 8 (2), pp. 214-235. p.224.

${ }^{42}$ Benedict Anderson highlights the role of museums along with the map and census in the $19^{\text {th }}$ century in creating the sense of a homogeneous and historically continuous community. Benedict Anderson, Imagined Communities Reflections on the Origin and Spread of Nationalism, 2004, Verso, London.

${ }^{43}$ Scott Redford, "What Have You Done for Anatolia Today?": Islamic Archaeology in the Early Years of the Turkish Republic, in Gülru Necipoglu Muqarnas, Volume 24, History and Ideology: Architectural Heritage of the "Lands of Rum", 2007, Brill, Leiden, The Netherlands, pp. 243-252.

${ }^{44} \mathrm{~N}$. Maksudyan, 'The Turkish Review of Anthropology and the Racist Face of Turkish Nationalism', Cultural Dynamics, 17(3), 2005, pp. 291-322.

${ }^{45}$ N. Maksudyan, 'The Turkish Review of Anthropology and the Racist Face of Turkish Nationalism', Cultural Dynamics, 17(3), 2005, pp. 291-322.

${ }^{46}$ Inan, Afet, 'Prolegomena to an outline of Turkish history', in Ahmet Ersoy, Maciej Gorny and Vangelis Kechriotis (eds), Modernism: Representations of National Culture. Central European University Press, Budapest - New York, 2010, pp. 54-61. Available online at: http://books.openedition.org/ceup/1027\#tocfrom1n1 47 Lewis, G. (1999) The Turkish Language Reform: A Catastrophic Success. Oxford: Oxford University Press. ${ }^{48}$ TNA: FO 371-17959 (1934) 'Turkey. Code 44 Files 264 (papers 7708 - end) - 640'. Annual Report on Turkey for 1933.

${ }^{49}$ The irrevocable consequences of the Turkish Language reform see Geoffrey Lewis, The Turkish Language Reform: A Catastrophic Success, Oxford University Press, Oxford, UK, 1999.

${ }^{50}$ I. Ayturk, 'Turkish Linguists against the West: The Origins of Linguistic Nationalism in Atatürk's Turkey', Middle Eastern Studies, 40(6), 2004, pp. 1-25. P.12.

${ }^{51}$ TNA: FO 371-17959 (1934) 'Turkey. Code 44 Files 264 (papers 7708 - end) - 640'. Annual Report on Turkey for 1933.

${ }^{52}$ Wendy M. K. Shaw, Whose Hittites, and Why? Language, Archaeology and the Quest for the Original Turks, in Michael L. Galaty and Charles Watkinson, Archaeology Under Dictatorship, New York: Kluwer

Academic/Plenum Publishers, 2004, pp 131-153.

${ }^{53}$ TNA: FO 371 371-17958 (1934) 'Turkey. Code 44 Files 256 - 264 (to paper 7365)'. Confidential Report on Turkish Personalities, dispatched from James Morgan to John Simon, 11 January 1934.

${ }^{54}$ Scott Redford, "'What have you done for Anatolia Today?": Islamic Archaeology in the Early Years of the Turkish Republic', in Gülru Necipoğlu (ed.) Muqarnas, Vol. 24, History and Ideology: Architectural Heritage of the "Lands of Rum", 2007, pp. 243-252. p.243.

${ }^{55}$ Inal, Kemal, Eğitimde İdeolojik Boyut. Doruk Yayıncılık, Ankara, Turkey, 1996.

${ }^{56}$ In September 1932, Resit Galip Bey 'was one of two vice-presidents of First Turkish Linguistic Congress at Constantinople, and shortly afterwards was appointed Minister of Education. He became an ardent champion of the Gazi's historical and linguistic ideas, but was over-zealous in reform of Stambul University, incurring enmity by wholesale dismissal of professors. He also incurred jealousy if the Gazi himself by having himself appointed president of "Institute of the Revolution", and had to resign post of Minister of Education in August 1933 on ground of ill-health'. TNA: FO 371 371-17958 (1934) 'Turkey. Code 44 Files 256 - 264 (to paper 7365)'. Confidential Report on Turkish Personalities, dispatched from James Morgan to John Simon, 11 January 1934. ${ }^{57}$ TNA: FO 371-17959 (1934) 'Turkey. Code 44 Files 264 (papers 7708 - end) - 640'. Annual Report on Turkey for 1933.

${ }^{58}$ Edelman, E. (2004) Erdogan and AK Party after two years in power: trying to get a grip on themselves, on Turkey, on Europe. WikiLeaks. https://wikileaks.org/plusd/cables/04ANKARA7211_a.html 